\title{
COMPUTER SIMULATION OF THERMAL AND HYDRAULIC PROCESSES IN NPP STEAM GENERATOR CHANNELS ON THE BASIS OF INTERVAL-ITERATIVE METHOD
}

\author{
O.V. Yefimov ${ }^{1}$, M.M. Pylypenko ${ }^{2}$, T.V. Potanina ${ }^{1}$, V.L. Kavertsev ${ }^{1}$, \\ T.A. Harkusha ${ }^{1}$, T.O. Yesypenko ${ }^{1}$ \\ ${ }^{1}$ National Technical University “Kharkiv Polytechnic Institute”, Kharkiv, Ukraine \\ E-mail:AVEfimov@kpi.kharkov.ua; \\ ${ }^{2}$ National Science Center "Kharkov Institute of Physics and Technology”, Kharkiv, Ukraine
}

The designing of NPP steam generators, which are complex technical systems, requires a large number of variant calculations, as result of which must be obtained both optimal integral characteristics of steam generators (total heat transfer surface, metal capacity, hydraulic circuits, etc.) and many of their local characteristics (distributions heat flux densities and temperatures, possible amplitudes of their pulsations and others). The complexity of NPP steam generators as technical systems is determined by their multi-parameter, the presence of a complex logical and functional relationship between the parameters, the presence of various restrictions on the change of parameters, the stochastic change of parameters during exploitation. The article presents methods of mathematical modeling of thermal and hydraulic processes in NPP steam generators and modular programs of their calculations in onedimensional formulation on the example of a steam generator with countercurrent (direct current) mutual motion of the coolant and the working substance. Logical and structural schemes of computer programs of thermal and hydraulic calculations of NPP steam generators are presented.

\section{INTRODUCTION}

The designing of NPP steam generators, which are complex technical systems, requires a large number of variant calculations, as result of which must be obtained both optimal integral characteristics of steam generators (total heat transfer surface, metal capacity, hydraulic circuits, etc.) and many of their local characteristics (distributions heat flux densities and temperatures, possible amplitudes of their pulsations and others) [1-7]. The complexity of NPP steam generators as technical systems is determined by their multiparameter, the presence of a complex logical and functional relationship between the parameters, the presence of various restrictions on the change of parameters, the stochastic change of parameters during exploitation $[9,10]$. Therefore, a sufficiently complete system analysis of possible designs of NPP steam generators cannot be performed without the use of modern computer-based computing technologies and without the creation of appropriate mathematical models. Mathematical models of NPP steam generators and their software implementations are subject to certain requirements.

In particular, together with the speed, they should provide the ability to perform optimization calculations of steam generators of different designs in a wide range of parameter changes and the use of different structural materials without entering additional initial data and changes in programs.

Thermal and hydraulic calculations of steam generators are the first basic calculations at the stage of their design, providing initial information for further calculations of strength and technical and economic indicators.
According to the degree of detail of the received information, thermal and hydraulic calculations of steam generators should be divided into estimated, onedimensional, two-dimensional and three-dimensional. For the purpose of the received information - on those intended for definition of geometrical characteristics of steam generators at the set parameters (constructive calculations), for definition of parameters of steam generators on various operating modes at their set designs (check calculations), for definition of optimum mode characteristics of steam generators (optimization calculations). It should be noted that computer programs for thermal and hydraulic calculations of steam generators, created on the basis of mathematical modeling, are widely used in automated control systems of power units during their operation at existing NPPs, to predict changes in parameters, functional diagnostics, reliability and residual life nodes, optimization of steam generators.

In order to create a unified program, which includes various modifications of thermal and hydraulic calculations, as a rule, a set of software modules is developed, which can be assembled using a control program, just such a set of programs that is needed to solve this particular problem. The positive side of the modular organization of programs is the ability to quickly adjust them when changing the purpose and detailing the calculations by changing the initial data in the modules or their replacement.

Consider the methods of mathematical modeling of thermal and hydraulic processes in NPP steam generators and modular programs for their calculations in one-dimensional formulation on the example of a steam generator with countercurrent (direct current) mutual motion of the coolant and the working substance. 
For steam generators with countercurrent or directflow mutual movement of the coolant and the working substance (or with equivalent multi-stroke motion) thermal and hydraulic calculations are largely reduced to the calculation of a single steam-generating channel $[1,3]$. In modern mathematical models in the case of one-dimensional calculation of the problem of heat transfer and hydraulic processes in the steam-generating channel are described mainly by a set of dependences below.

Equation of heat balance in the steam-generating channel:

$$
\begin{aligned}
& G_{1} \int_{t_{0}}^{t_{1}} c_{p} d t=\pi \cdot d_{\text {outer }} \int_{0}^{z} q(z) d z \\
& G_{1} \int_{t_{0}}^{t_{1}} c_{p} d t=G_{2}\left(i-i_{0}\right) .
\end{aligned}
$$

The equation of heat transfer in the steam-generating channel:

$$
\begin{gathered}
q=k\left(t_{1}-t_{2}\right) ; \\
\frac{1}{k}=\frac{1}{\alpha_{1}}+R_{w}+R_{\mathrm{op}}+R_{\text {sedim }}+\frac{1}{\alpha_{2}},
\end{gathered}
$$

where $R_{w}$-the thermal support of the tubes walls; $R_{o p}$ - the thermal support of the layer of oxide pellicles; $R_{\text {sedim }}$ - the thermal support of the layer of sediments.

Equations for determining the pressure and hydraulic resistance in the steam-generating channel along the paths of the coolant and the working substance:

where

$$
P=P_{0} \pm \sum \Delta P_{l o c} \pm \int_{0}^{z}(d P / d z)_{0} d z
$$

$$
(d P / d z)_{0}=(\partial P / \partial z)_{\text {h.c. }}+(\partial P / \partial z)_{\text {fl. accel }} \pm(\partial P / z)_{\text {level }} \text {. }
$$

Dependences of connection of temperatures of feed water $t_{\text {f.w. }}$ i пари $t_{s}$ with their enthalpies $i_{\text {f.w. }}, i_{s}$ and pressures $P_{\text {f.w. }}, P_{s}$ in the steam generating channel:

$$
t_{\text {f.w. }}=f_{1}\left(i_{\text {f.w. }}, P_{\text {f.w. }}\right) ; t_{S}=f_{2}\left(P_{S}\right) ; t_{s}=f_{3}\left(i_{s}, P_{s}\right) .
$$

Dependencies that determine the values of thermophysical properties of the coolant, working substance and structural materials as a function of their temperature $t$ and pressure $P$ in the steam generating channel:

$$
\{\text { Properties }\}=f_{4}(t, P) .
$$

Dependences for calculations of heat transfer coefficients on the sides of the coolant $\alpha_{1}$ and the working substance $\alpha_{2}$ in the functions of their determining parameters in the steam generating channel:

$$
\begin{aligned}
& \alpha_{1}=f_{5} \text { (parameters); } \\
& \alpha_{2}=f_{6} \text { (parameters). }
\end{aligned}
$$

Dependences for the calculation of the coefficients of hydraulic resistance to the flow of the coolant and the working substance and the true volumetric vapor content of the steam-water mixture as a function of the flow parameters in the steam-generating channel:

$$
\begin{aligned}
& \xi=f_{7} \text { (parameters); } \\
& \phi=f_{8} \text { (parameters). }
\end{aligned}
$$

Dependencies that determine the limits of heat transfer modes from the feed water and steam in the steam-generating channel:

$$
F(q, x, \rho w, p \ldots)=0 .
$$

In these dependencies there are no values associated with heat loss to the environment and energy dissipation. If necessary, they can be entered into the equation (1), (2).

In the mathematical model of the dependence of the form (1)-(13) determine the solution of the onedimensional problem of thermal and hydraulic calculations of the steam generator of any design when specifying the equations (7)-(13). The latter are either an adequate description of the tables of thermodynamic and thermophysical properties of substances and materials (equations (7), (8)), or empirical or semiempirical dependences (equation (11)-(13)). The specific form of equations (7)-(13) depends on the type and design features of steam generators, parameters and types of coolants and working substances used, construction materials used, operating factors. The interval-iterative method is used to solve the system of equations (1)-(13) in the mathematical model. The temperature of the heat carrier at the entrance to the steam generating channel $t_{l}$ is taken as an independent variable. The range of its complete change in the channel to the outlet temperature $t_{2}$ is divided into $N$ intervals $\delta t_{1 i}$ determined by the nodes of the partition $T_{i}$, where $i=0,1,2, \ldots k$ - the node number. Assuming that the heat flux density within the intervals varies linearly, and introducing for the values of the specific isobaric heat capacity of the coolant and the heat flux density designation

$$
\begin{aligned}
& c_{p_{i,(i-1)}}=c_{p}^{\text {mid }}\left(\text { by "interval" } t_{1}, t_{(i-1)}\right), \\
& q_{i,(i-1)}=0.5\left(q_{i}+q_{i-1}\right),
\end{aligned}
$$

you can write equations (1) and (2) in the form

$$
\begin{gathered}
z_{i}=\sum_{k=1}^{i} \delta z_{k}=\frac{G_{1}}{\pi d_{6}} \sum_{k=1}^{i} \frac{c_{p_{k,(k-1)}} \delta t_{1 k}}{q_{k,(k-1)}} \\
i_{i}=i_{0}+\sum_{k=1}^{i} \delta i_{k}=i_{0}+\frac{G_{1}}{G_{2}} \sum_{k=1}^{i} c_{p_{k,(k-1)}} \delta t_{1 k} .
\end{gathered}
$$

Assuming $d P / d z$ a constant value within the interval the considered, equation (5) is written as

$$
\begin{gathered}
P_{i}=P_{0}-\sum_{k=0}^{i} \delta P_{k}= \\
=P_{0}-\sum_{k=1}^{i}\left(\frac{d P}{d z}\right)_{k-1} \delta z_{k}+\sum_{k=0}^{i} \Delta P_{\mathrm{M}} \delta_{j k},
\end{gathered}
$$

where $j$ - the number of the node corresponding to the element of the path having a local hydraulic resistance $\Delta P_{i} ; \delta_{j k}=0$ at $j \neq k$ and $\delta_{j k}=1$ at $j=k$;

$$
\delta z_{k}=\frac{G_{1}}{\pi d_{\text {int }}} \frac{c_{p_{k,(k-1)}}}{q_{k,(k-1)}} \delta t_{1 k}
$$




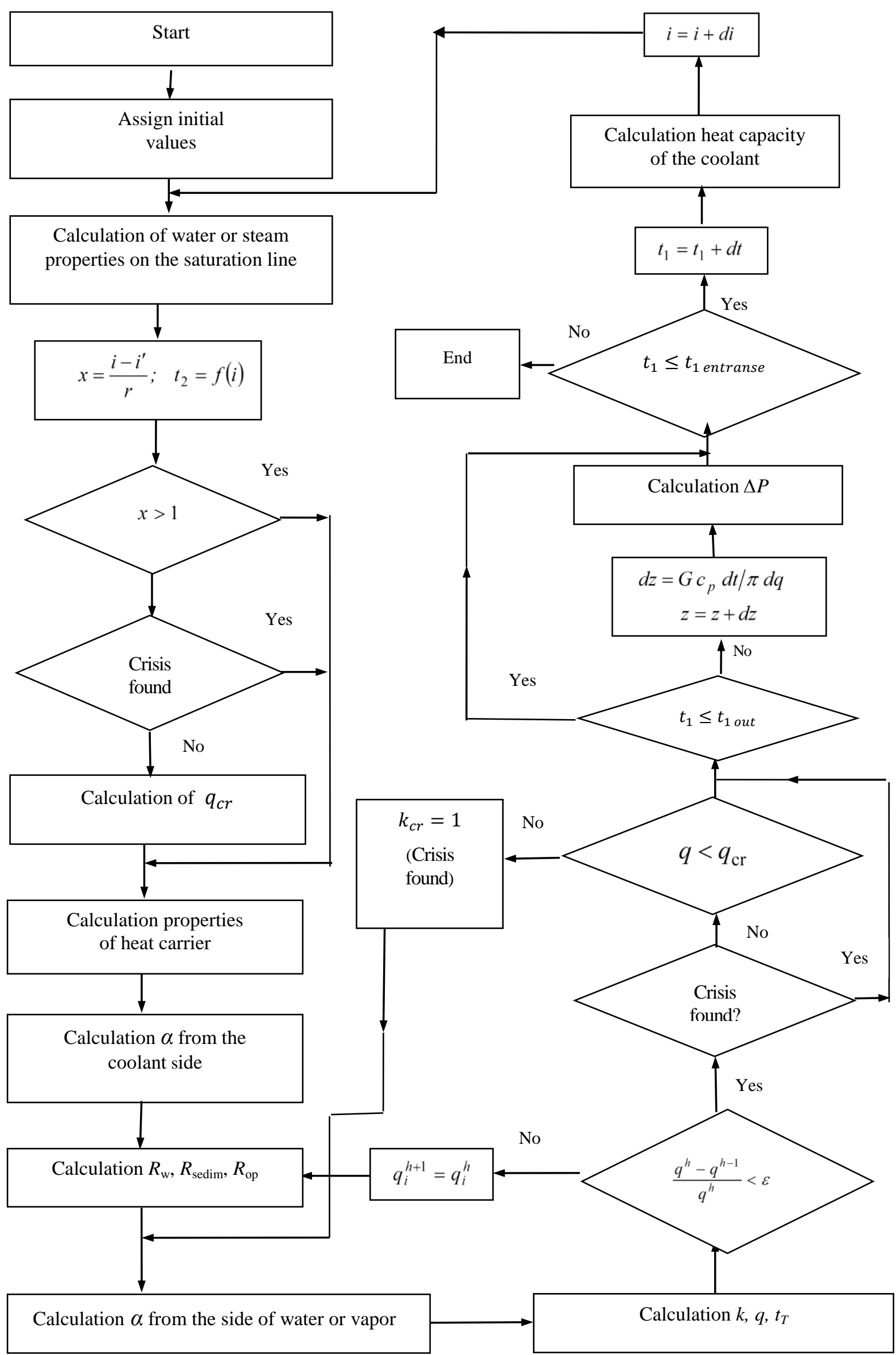

Fig. 1. Logical-structural scheme of the program of thermohydraulic calculation of the NPP steam generator with countercurrent (direct-flow) scheme of mutual movement of the heat carrier and working substance 
The calculation is performed sequentially, from node to node. For each node, knowing $t_{1 i}$ the equations (7) and (17) are calculated the corresponding values $t_{2 i}$. Then the values are determined $\alpha_{1 i}, \alpha_{2 i}$, $R_{w_{i}}, R_{\text {sedim }_{i}}, R_{\mathrm{op}_{i}}, k_{i}, q_{i}, t_{\mathrm{w}_{i}},(d P / d z)$.

Since equations (8)-(13), which determine these values, are nonlinear, the calculation is performed by the method of successive approximations with a given accuracy of convergence in heat flux density, i.e. until the condition

$$
\left|\frac{q_{i}^{h+1}-q_{i}^{h}}{q_{i}^{h}}\right| \leq \varepsilon
$$

Top indexes in formula (20) indicate the iteration number. According to the values found $q_{i}$ and $q_{i-1}$, are $z_{i}$ in formula (16) and $P_{i}$ in formula (18).

The calculation ends after reaching the final node, i.e. the limit value of the coolant temperature at the outlet of the steam-generating channel $t_{2}$.

The above method solves the problem of direct structural calculation of thermal and hydraulic processes. To solve the inverse problem, other methods of solving the system of equations (1)-(13) and other computational algorithms are used. The solution of the inverse problem can be obtained by performing a direct calculation with the introduction of variation of one of the defined parameters. There are different algorithms for finding the solution of the inverse problem. For example, the method of gradient search for a solution with a given accuracy of convergence along the length of the channel $l$. But such a mathematical method is not effective enough to calculate steam-generating channels with low temperature pressures, when to satisfy the condition

$$
\left|1-l_{\text {calc }} / l_{\text {spec }}\right| \leq \varepsilon
$$

almost impossible due to the contradiction between the actual accuracy of the calculation and the specified value $\varepsilon$. It is more convenient to set the condition of the end of the calculation in the form

$$
l_{\text {calc }} \geq l_{\text {spec }} .
$$

In this case, the accuracy of the solution of the inverse problem is completely determined by the step of the calculation scheme.

The logical-structural scheme of the program of constructive thermohydraulic calculation of the countercurrent (direct-flow) steam generator, which provides the solution of the systems of equations (1)-(13), is shown in Fig. 1.

This program uses separate subroutines-modules that implement the following calculations: parameters of thermodynamic and thermophysical properties of water and water vapor; parameters of thermodynamic and thermophysical properties of the coolant; coefficients of linear expansion and thermal conductivity of structural materials; heat transfer coefficients from water and steam; heat transfer coefficients from the heat carrier; thermal resistance of heat exchange tubes; conditions of transition to the worsened heat exchange from water and steam; pressure gradients along the paths of the coolant and the working substance. Each of the subroutines has its own internal logical structure, which provides a choice of the currently required calculation of mathematical relations. In particular, when calculating the heat transfer coefficients $\alpha_{1}$ and $\alpha_{2}$, it is necessary to take into account the differences in the modes of heat removal in different elements (areas of the heat transfer surface) of the steam generator.

This condition in mathematical modeling is most fully met by the method of dividing the steam generator into the following zones:

- economizer zone: $N u=F_{1}\left(\operatorname{Re}, \operatorname{Pr}, t_{w}\right)$; area of existence of the zone: $t_{w}<t_{S}$;

- boiling zone of heated liquid (surface boiling): $\alpha=\alpha\left(\alpha, \alpha_{\text {boil }}, \Delta t\right)$; area of existence of the zone: $x<0$, $t_{w}>t_{S}$

- the zone of the developed boiling of steam-water mix: $\alpha=\alpha(q P, \rho w, x)$; area of existence of the zone: $0<x<x_{c r}$;

- "closed" zone of impaired heat transfer: $\alpha=\alpha(q P$, $\rho w, x)$; area of existence of the zone: $x_{c r}<x<1$;

- steam overheating zone: $N u=F_{2}\left(\operatorname{Re}, \operatorname{Pr}, t_{w}\right)$; area of existence of the zone: $x>1$.

This division into zones corresponds, for example, to the logical-structural scheme of the subroutine of the module for calculating the heat transfer coefficients on the water and steam side, shown in Fig. 2, which is included as a separate unit in the program of thermohydraulic calculation of the steam generator (see Fig. 1).

\section{CONCLUSIONS}

The methods of mathematical modeling of thermal and hydraulic processes and the programs of their calculations on the computer are suitable for designs of steam generators in which the scheme of mutual movement of the heat carrier and working substance is countercurrent or direct-flow. For designs of steam generators with more complex mutual movement of the coolant and the working substance, these techniques can be used only with the introduction of correction factors. 


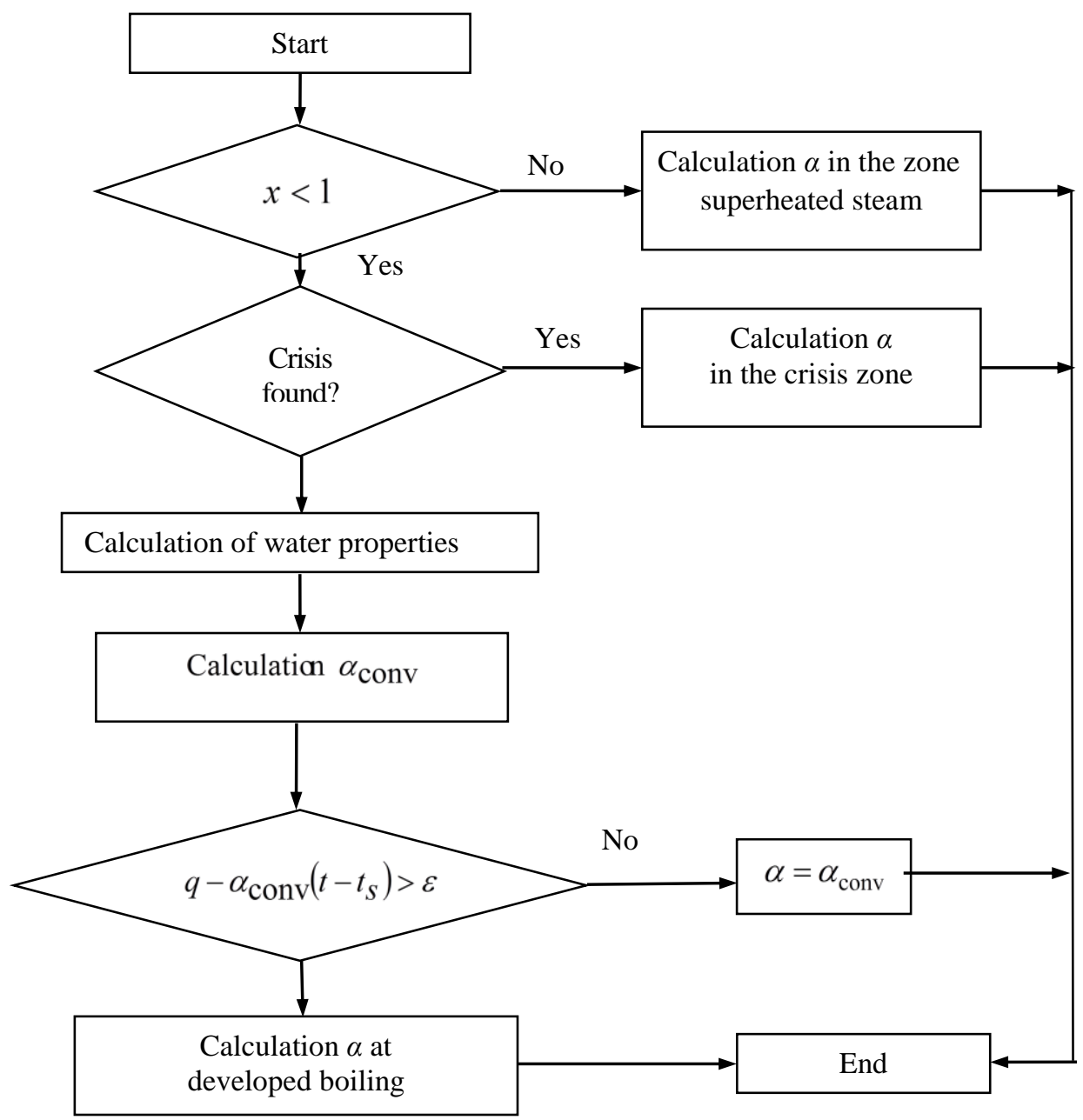

Fig. 2. Logical-structural scheme of the subroutine of the module of calculations of heat transfer coefficients from water and steam in steam-generating channels of NPP steam generators

\section{REFERENCES}

1. V.M. Budov, V.A. Pharafonov. Design of the main equipment of nuclear power plants. M.: "Energoizdat", 1985, 264 p.

2. V.V. Girnis, V.A. Fedulov, G.V. Filatkin. Installation of equipment for steam generating plants and reactors of nuclear power plants. M.: "Energoizdat", 1982, 328 p.

3. A.P. Kovalev. Steam generators. M.: „Energoatomizdat", 1985, $376 \mathrm{p}$.

4. T.H. Margulova. Calculation and design of steam generators of nuclear power plants. M.: "Energoizdat", 1982, $192 \mathrm{p}$.

5. P.A. Andreev, M.I. Greenman, Yu.W. Smolkin. Optimization of NPP thermal power equipment. M.: "Atomizdat", 1975, 224 p.

6. E.F. Ratnikov. Installation of NPP equipment. Sverdlovsk: "UPI", 1985, 75 p.

7. O.V. Yefimov, M.M. Pylypenko. Constructions, materials, processes and calculations of reactors and steam generators of NPPs: Textbook manual. Kharkiv: NTU “KhPI", 2009, 307 p.

8. A.V. Yefimov, D.I. Kukhtin, T.V. Potanina, T.A. Harkusha, V.L. Kavertsev. Automated decision support for operating personnel of NPP power units by the criterion of technical and economic efficiency, taking into account reliability indicators // Nuclear and Radiation Safety. 2018, N 2(78), p. 11-19.

9. O.V. Yefimov, M.M. Pylypenko, T.V. Potanina, V.L. Kavertsev, T.A. Harkusha. Reactors and steam generators of NPP power units: schemes, processes, materials, structures, models. Kharkiv: LTD "Infact", 2017, $420 \mathrm{p}$.

10. O. Yefimov, M. Pylypenko, T. Potanina. Materials and decision support systems in the nuclear power industry: monography. LAP Lambert Academic Publishing. Riga, Latvia, 2020, 135 p.

11. T.V. Potanina, A.V. Yefimov, T.A. Garkusha, T.A. Yesypenko. Application of interval analysis methods for safety and reliability assessment of NPP power units // Nuclear and radiation safety. 2018, N 3(79), p. 23-29.

12. A.V. Yefimov, T.V. Potanina. Application of interval analysis for improving reliability of hardness value spread for nuclear structural materials // Problems of Atomic Science and Technology. 2020, N 1(125), p. 206-210. 


\title{
КОМПЬЮТЕРНОЕ МОДЕЛИРОВАНИЕ ТЕПЛОВЫХ И ГИДРАВЛИЧЕСКИХ ПРОЦЕССОВ В КАНАЛАХ ПАРОГЕНЕРАТОРОВ АЭС НА ОСНОВЕ ИНТЕРВАЛЬНО-ИТЕРАЦИОННОГО МЕТОДА
}

\author{
А.В. Ефимов, Н.Н. Пилипенко, Т.В. Потанина, В.Л. Каверцев, Т.А. Гаркуша, Т.А. Есипенко
}

Проектирование парогенераторов АЭС, являющихся сложными техническими системами, требует проведения большого количества вариантных расчетов, в результате которых должны быть получены как оптимальные интегральные характеристики парогенераторов (общая поверхность теплообмена, металлоемкость, гидравлические сопротивления контуров и др.), так и многие их локальные характеристики (распределение плотности тепловых потоков и температур, возможные амплитуды их пульсаций и др.). Сложность парогенераторов АЭС как технических систем определяется их многопараметричностью; наличиями сложной логической и функциональной связи между параметрами и разных ограничений на изменение параметров; стохастичностью изменений параметров во время эксплуатации. В статье приведены методики математического моделирования тепловых и гидравлических процессов в парогенераторах АЭС и модульные программы их расчетов в одномерной постановке на примере парогенератора с противоточным (прямоточным) взаимным движением теплоносителя и рабочего вещества. Предложены логико-структурные схемы компьютерных программ тепловых и гидравлических расчетов парогенераторов АЭС.

\section{КОМП'ЮТЕРНЕ МОДЕЛЮВАННЯ ТЕПЛОВИХ І ГІДРАВЛІЧНИХ ПРОЦЕСІВ У КАНАЛАХ ПАРОГЕНЕРАТОРІВ АЕС НА ОСНОВІ ІНТЕРВАЛЬНО-ІТЕРАЦЙНОГО МЕТОДУ}

\author{
О.В. Сфімов, М.М. Пилипенко, Т.В. Потаніна, В.Л. Каверцев, Т.А. Гаркуиа, Т.О. Єсипенко
}

Проектування парогенераторів АЕС, які $є$ складними технічними системами, вимагає проведення великої кількості варіантних розрахунків, у результаті яких мають бути отримані як оптимальні інтегральні характеристики парогенераторів (загальна поверхня теплообміну, металоємність, гідравлічні опори контурів та інші), так і багато їх локальних характеристик (розподіли густини теплових потоків і температур, можливі амплітуди їх пульсацій та інші). Складність парогенераторів АЕС як технічних систем визначається їх багатопараметричністю; наявністю складного логічного і функціонального зв'язку між параметрами і різних обмежень на зміну параметрів; стохастичністю зміни параметрів під час експлуатації. У статті наведені методики математичного моделювання теплових і гідравлічних процесів у парогенераторах AEC і модульні програми їх розрахунків у одномірній постановці на прикладі парогенератора 3 протитечійним (прямотечійним) взаємним рухом теплоносія і робочої речовини. Наведені логіко-структурні схеми комп’ютерних програм теплогідравлічного розрахунку парогенераторів АЕС. 